Portland State University

PDXScholar

11-21-1997

\title{
Age Related Changes in the Activity and the Responsiveness of the Renin-angiotensin System in the 15 Month Old Rat
}

Mlchele McKee Thompson

Portland State University

Follow this and additional works at: https://pdxscholar.library.pdx.edu/open_access_etds

Part of the Biology Commons

Let us know how access to this document benefits you.

\section{Recommended Citation}

Thompson, Mlchele McKee, "Age Related Changes in the Activity and the Responsiveness of the Reninangiotensin System in the 15 Month Old Rat" (1997). Dissertations and Theses. Paper 5409.

https://doi.org/10.15760/etd.7281

This Thesis is brought to you for free and open access. It has been accepted for inclusion in Dissertations and Theses by an authorized administrator of PDXScholar. Please contact us if we can make this document more accessible: pdxscholar@pdx.edu. 


\section{THESIS APPROVAL}

The abstract and thesis of Michele McKee Thompson for the Master of

Science in Biology were presented June 27, 1997 and accepted by the thesis committee and the department.

COMMITTEE APPROVALS:

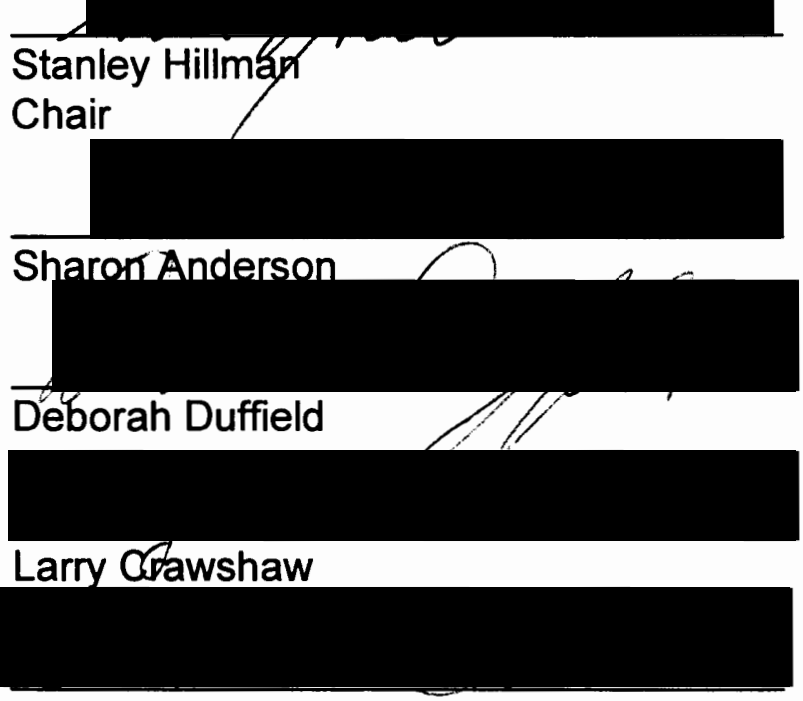

Dannelle Stevens

Representative of the Office of

Graduate Studies

DEPARTMENT APPROVAL:
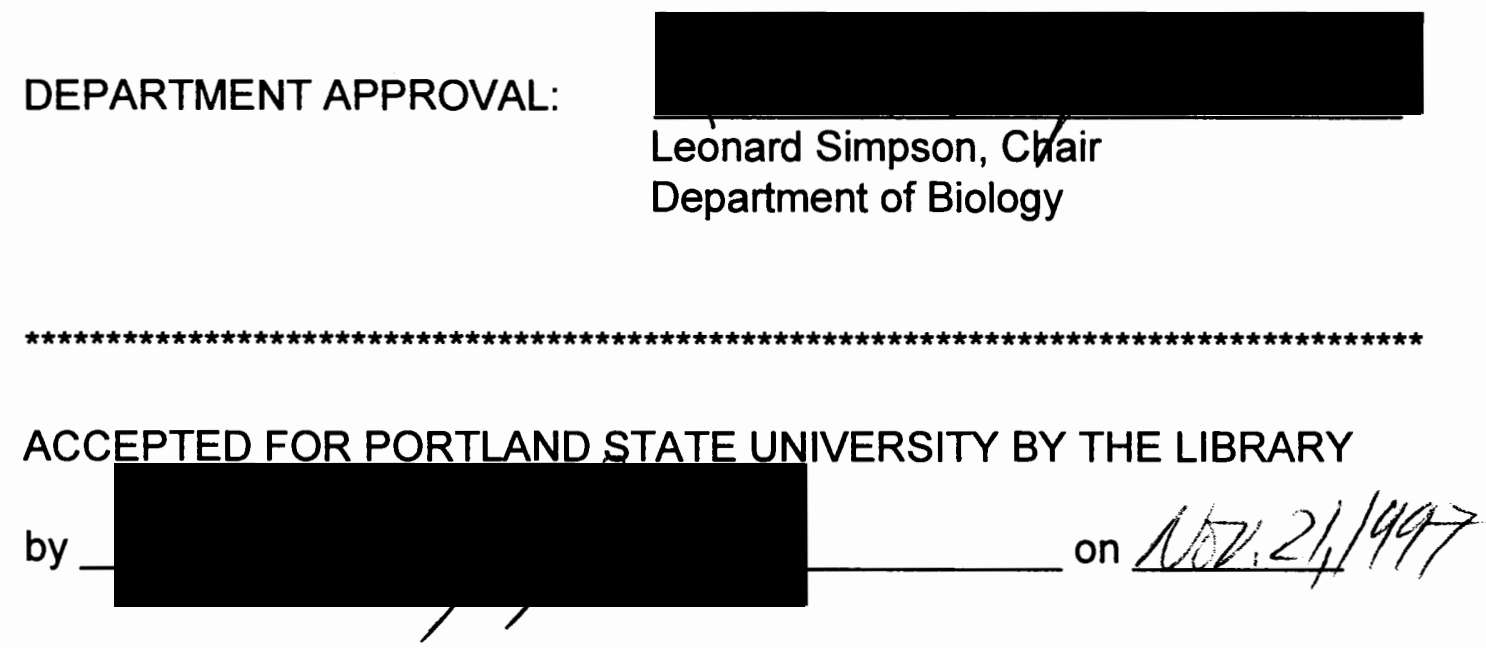


\section{ABSTRACT}

An abstract of the thesis of Michele McKee Thompson for the Master of Science in Biology presented June 27, 1997.

Title: Age related changes in the activity and the responsiveness of the reninangiotensin system in the 15 month old rat.

Progressive deterioration of renal function is one consequence of aging. Glomerular maladaptation is one aspect of this and includes increased glomerular capillary hypertension and a reduced ultrafiltration coefficient, which can lead to glomerular sclerosis and proteinuria. In the aging rat, angiotensin converting enzyme inhibitors (CEI) lower proteinuria $\left(U_{\text {prot }} V\right)$ and decrease glomerular sclerosis $(2,18,24,45)$. Accordingly, alterations in the circulating and renal renin-angiotensin system (RAS) are hypothesized to play a role in the pathogenesis of renal disease in the aging rat. Previous studies using rat models have demonstrated a lower responsiveness to converting enzyme inhibitor treatment in the older rat compared to the young and diabetic models $(2,12)$. However, these results are not found consistently $(7)$. We treated young ( 3 month old) and older (15 month old) Sprague-Dawley rats with the converting enzyme inhibitor, enalapril, to investigate the responsiveness to this treatment, of the older rat compared to the young rat. 
Blood pressure, proteinuria, renal function, and blood and renal reninangiotensin component concentrations were compared in young and older male Sprague-Dawley rats treated for 4 weeks with two dose levels of enalapril. Young and older untreated controls received no enalapril treatment. All rats were normotensive at baseline and the older rats were proteinuric. Enalapril reduced systolic blood pressure in both age groups; however, this treatment failed to significantly reduce proteinuria in the older rats. Renal function decreased in the older rats. Enalapril treatment did not improve the renal function of either the young or the older rat. Mean arterial pressure was reduced, with enalapril treatment, in the young, but not the older rats. Biochemical RAS measurements were not altered with age. Plasma renin concentration, kidney angiotensin II (Ang II) and blood Ang II responded appropriately with the converting enzyme inhibitor enalapril, and showed no age-related responses to this treatment. We conclude that the 15 month old rat does not exhibit an age-related alteration in response to converting enzyme inhibition when compared to the young rat. At this transition age, the decline in renal function does not appear to be a consequence of an altered reninangiotensin system. 
AGE RELATED CHANGES IN THE ACTIVITY AND THE

RESPONSIVENESS OF THE RENIN-ANGIOTENSIN SYSTEM IN THE 15 MONTH OLD RAT

by

MICHELE MCKEE THOMPSON

A thesis submitted in partial fulfillment of the

requirements for the degree of

MASTER OF SCIENCE

in

BIOLOGY

Portland State University

1997 


\section{ACKNOWLEDGMENTS}

The completion of this document involved the collective efforts of several generous and patient people. Stan Hillman gave me guidance and direction while demanding my best performance. In my three years at PSU, I have come to know the stability that is Stan Hillman. His devotion and support of his students makes him much more than a professor to all that have contact with him. He is a life teacher.

Sharon Anderson generously gave me the support, flexibility and latitude to take on and complete this project. Her presence and standards influence my life and work. She has served as and will continue to be an ideal role model. I will always admire the grace with which she balances research, clinical medicine, administration and teaching.

Terry Oyama, Tom Kennefick, Patricia Alley, Frank Kelly and Hem Deohdar are responsible for maintaining my spirit during this project. Their humor, kindness, support, advice and patience assisted me more than they can ever know. Terry, thank-you for the perspective and pragmatism. Tom, thank-you for guiding my path and focus, your advice always cleared the way.

My mother and father, Laurie and Stephan Thompson, have provided the love and encouragement that has made this project possible. 
TABLE OF CONTENTS

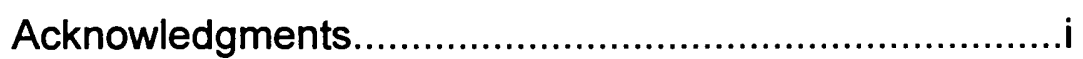

List of Tables.................................................................

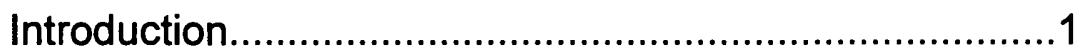

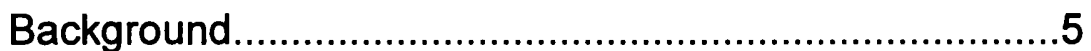

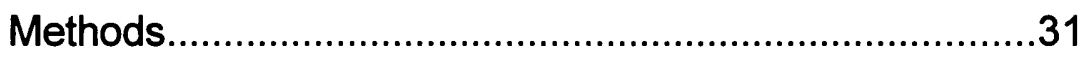

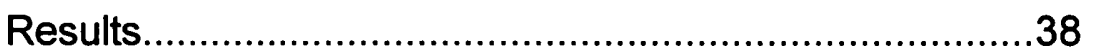

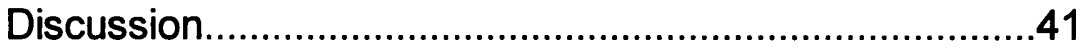

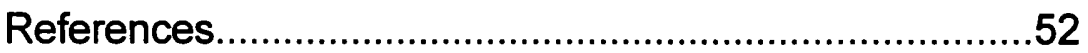




\section{LIST OF TABLES}

1. Baseline and post treatment measurement.............46

2. Systemic and renal function measurements...........47

3. Renin-angiotensin system measurements..............48

4. Statistical results of baseline and post-treatment measurements....................................................49

5. Statistical results of systemic and renal function measurements.

50

6. Statistical results of renin-angiotensin system measurements. 


\section{INTRODUCTION}

Aging involves a variety of structural and functional alterations in the kidney. These changes may relate, in part, to age-related changes in reninangiotensin system action. Plasma concentrations of renin $(17,44)$ and aldosterone (44) are reduced in elderly human subjects. Similar changes begin 10 months after birth in the rat (life span of 2-3 years), but the most dramatic changes, including a decline in renin, occur after 20 months of age (12). Both decreased renal renin mRNA and protein synthesis, and a blunted release of renin to the circulation, contribute to reduced plasma levels (27). Possible causes include nephrosclerosis of the juxtaglomerular apparatus, decreased sympathetic stimulus, and inactive enzyme $(44,21)$.

Another alteration with age occurs in angiotensin II (Ang II) concentration where in a limited number of rat studies, plasma Ang II levels were inversely correlated with age (5). In contrast, in the senescent rat kidney, the tissue Ang II concentration is elevated at the advanced age of 24 months (5).

The effect of a lower plasma Ang II concentration on the aged kidney is not yet understood. Inhibition of the angiotensin converting enzyme, by inhibitory drugs such as enalaprilat resulted in vasodilation of the old kidney that is not observed in the young (7), although Anderson et al (2) and Corman and Michel (12) failed to confirm this observation. Consequently, it is proposed that reduced Ang II leads to up-regulation of $A T_{1}$ receptors resulting 
in hypersensitivity to the remaining Ang II concentration or to exogenous Ang II $(2,7)$. Furthermore, separate circulating/vascular and tubular renal compartments may change differently, so that there is a down-regulation of the circulating/vascular renin and Ang II, which enhances the response to exogenous Ang II (43), accompanied by a concurrent up-regulation of the tubular RAS.

Mechanisms of age-related renal disease remain poorly understood; however, there is evidence implicating hemodynamic forces in this process. Lower afferent arteriolar resistance in the old rat, combined with the unchanged efferent arteriolar resistance, leads to glomerular capillary hypertension (2). Older rats have a reduced glomerular capillary ultrafiltration coefficient which reflects either reduction of filtration area by mesangial cell contraction, or reduced hydraulic conductivity (2). These glomerular stresses, in addition to an age-dependent decline in nephron number, develop into glomerular sclerosis, which is reflected in proteinuria and eventually leads to renal failure (2).

Converting enzyme inhibitors (CEI) lower proteinuria, and albuminuria, and decrease glomerular sclerosis $(2,18,24,45)$. CEI often reduces systolic blood pressure, but this adjustment alone will not always prevent glomerular sclerosis (2). The multiple mechanisms for this have not been fully explained $(25,27,45)$, but several possibilities for reducing potential glomerular sclerosis 
are: 1) reduction of capillary tension within the glomerulus; 2) improved filtration by the glomerular basement membrane (45); and 3) decreased stimulation of pressure-sensitive sclerosis mediators (2). Though the benefit of CEI is apparent, some studies have shown enzyme inhibition to be less effective in the aging kidney, compared to the younger one $(2,12)$.

Vascular responses in aging rats vary from study to study. The blood pressure response to Ang II infusion was enhanced in old rats (19-22 months; 7), though Tank et al. (43) failed to confirm this observation in less aged rats (15 months). Infusion of Ang II and the vasoconstrictor endothelin-1 induced greater changes in GFR and RPF in older as compared to young rats (43). CEI failed to cause arteriolar vasodilation in the old kidney in some $(2,12)$, but not all (7) studies, which resulted in variable RPF and GFR responses $(2,7)$. Furthermore, no consensus exists on the differential SBP response to $\mathrm{CEl}$ in the older compared to young rats $(2,7,12,18)$.

This investigation explored specific age-related changes in the activity and responsiveness of the renin-angiotensin system (RAS) in the course of normal aging in the rat. Systemic and renal functional parameters and RAS activity were measured in the untreated animal, and in rats receiving either low or high doses of the CEI enalapril. Studies were conducted in young adult (3month-old) rats, and in middle-aged rats (age 15 months). The study was designed to test the hypothesis that the older animals would be less 
responsive to the $\mathrm{CEI}$, and thus exhibit lesser or absent responses to this treatment.

Based on previous studies $(2,7,12)$, we anticipated a modified functional response to $\mathrm{CEI}$ in the older animal. Systemic and renal functional responses to enalapril were investigated with systolic blood pressure, mean arterial pressure, glomerular filtration rate, renal plasma flow and filtration fraction measurements. Age-related responses to CEI would predict a lessened pressor reaction in systolic blood pressure and mean arterial pressure, and no improvement of the decreased glomerular filtration rate and renal plasma flow in the older kidney. Evidence of further alterations of the systemic and renal RAS in the older rat were expected from biochemical data. Age-related differences in RAS activity in both untreated and treated animals were evaluated by measurement of plasma renin concentration, blood Ang II concentration, and kidney Ang II concentration. A suppressed systemic RAS, as expected with aging, would lead to reduction of the usual CEI responses, increased plasma renin concentration and decreased blood Ang II concentration. Up-regulation of the renal RAS with aging would tend to prevent the depression of kidney Ang II concentration in the older treated rat when compared to the young. 


\section{BACKGROUND}

\section{Mammalian Kidney}

The kidneys control the composition and volume of body fluids within narrowly defined limits by varying the excretion of water and solutes and regulating the excretion of essential metabolites. The kidney also produces and secretes enzymes and hormones such as renin, erythropoietin and 1,25dihyroxyvitamin $D_{3}$.

\section{Anatomy}

The kidneys are two bean shaped organs lying in the retroperitoneal space. They are connected to the rest of the body at the renal hilum, by the renal artery, renal vein, lymphatics, nerves and the pelvis of the ureter.

The kidney is divided into three regions: the cortex, the medulla and the pelvis. Blood enters the kidney through the renal artery, which branches in order to the interlobar arteries, to the arcuate arteries, to the interlobular arteries, leading to the afferent arteriole which branches into a parallel convoluted network of capillaries called the glomerulus. The capillaries of the

glomeruli converge into efferent arterioles which divide into a fine capillary 
network known as the vasa recta. The vasa recta supplies the nephron tubule before draining into the interlobular veins. The glomerulus is the only capillary bed in the entire body that is both fed and drained by arterioles.

The functional unit of the kidney is the nephron. The adult rat kidney contains 30,000 to 34,000 nephrons while the human kidney contains about $0.8 \times 10^{6}$ to $1.2 \times 10^{6}$ nephrons $(33,36)$. The basic components of the nephron include the renal corpuscle (consisting of the glomerulus and the Bowman's capsule), the proximal tubule (PT), the loop of Henle, the distal tubule and the connecting segment. The collecting duct drains into the renal pelvis, which empties into the ureter. The collecting duct is not considered part of the nephron because embryologically it arises from the ureteric bud. However, the collecting duct is interrelated functionally; therefore the term nephron will include the entire collecting duct for this discussion.

\section{The Nephron}

Nephrons with a short loop of Henle and those with a long loop of Henle make up two populations within the kidney. The loop of Henle is comprised of the straight portion of the proximal tubule, or pars recta, the thin limb segments, and the straight portion of the distal tubule, or thick ascending limb. Cortical nephrons have short loops of Henle. The juxtamedullary nephrons have long loops of Henle that extend deep into the medullary papilla. In the human kidney, there are approximately seven times more short 
than long-looped nephrons (33). In the rat kidney, approximately $28 \%$ of the nephrons are juxtamedullary nephrons (40).

\section{Glomerulus}

The renal corpuscle is a capillary network lined by a thin layer of endothelial cells; a central region of mesangial cells with surrounding mesangial matrix material; visceral epithelial cells and the associated glomerular basement membrane; and the parietal epithelial layer of Bowman's capsule with its basement membrane. Between the two epithelial layers is a narrow cavity called the Bowman's space, also called the urinary space. The general term glomerulus will be used to refer to this system.

The glomerulus is responsible for the production of a plasma ultrafiltrate that enters Bowman's capsule and continues through the nephron. The filtration barrier between the blood and the urinary space is composed of a fenestrated endothelium, the glomerular basement membrane, and the slit pores between the foot processes of the visceral epithelial cells. The endothelial cells form the initial barrier to the passage of blood constituents from the capillary lumen to the Bowman's space. The visceral epithelial cells, also called podocytes, are the largest cells in the glomerulus. They make up long cytoplasmic processes that extend from the main cell body and divide into individual foot processes that come into direct contact with the glomerular basement membrane. 
The mesangial cells and their surrounding matrix material make up the mesangium which is separated from the capillary lumen by the endothelium. The mesangial cell may represent a specialized pericyte and thus possess many of the functional properties of smooth muscle cells (36).

\section{Glomerular basement membrane}

The glomerular basement membrane is composed of a central dense layer, the lamina densa, and two thinner, more electron lucent layers, the lamina rara externa and the lamina rara interna. The basement membrane is the principal structure responsible for the permeability properties of the glomerulus. The glomerular basement membrane possesses negativelycharged sites that influence the filtration of macromolecules. Ultrastructural studies have provided evidence that the glomerular basement membrane constitutes both a size selective and charge selective barrier.

\section{Filtration}

The mammalian glomerulus is specialized for filtration. In vascular filtration/ultrafiltration, the blood supply provides a hydrostatic pressure for fluid filtration across capillaries. The podocytes support the filtration membrane against the hydrostatic pressure gradient. The filtrate is delivered into Bowman's capsule at the start of the proximal convoluted tubule. Filtrate formation in the glomerulus is governed by Starling forces. 


$$
\text { Flux }=K\left(P_{G C}-P_{B C}\right)-\Theta\left(\Pi_{G C}-\Pi_{B C}\right)
$$

$K$ represents the filtration coefficient, $P_{G C}$ and $P_{B C}$ represent the glomerular capillary and Bowman's Capsule hydrostatic pressure, while $\Pi_{\mathrm{GC}}$ and $\Pi_{\mathrm{BC}}$ represent the colloid osmotic forces of these spaces. $\Theta$ symbolizes the reflection coefficient of the glomerulus.

Filtration occurs if the sum of the forces promoting fluid passage across the filter into the tubule exceeds the sum of forces promoting uptake of fluid from the tubule across the filter. The forces are a transcapillary hydraulic pressure gradient and a transcapillary oncotic pressure gradient. The force promoting filtration out of the glomerulus is primarily hydraulic, because the colloid oncotic pressure in the Bowman's space and proximal tubule is nearly zero (since filtration is essentially impermeable to protein). The main determinant of passage through the glomerulus is molecular size. Substances of increasing size are retained with increasing efficiency until about 70,000 $\mathrm{kDa}$ where very little is filtered. Filtration also depends upon ionic charge, and negatively charged proteins are retained to a greater extent than would be predicted by size alone. As plasma is drained out of the glomerular capillaries it is losing hydraulic pressure, while gaining oncotic pressure, and thus losing the force of filtration, so only about $20 \%$ of the plasma is filtered.

\section{Glomerular filtration rate(GFR)}

Glomerular filtration rate (GFR) is equal to the product of the net 
ultrafiltration pressure, the hydraulic permeability, and the filtration area.

$$
G F R=L_{p} X \text { area } X P_{\text {net }}
$$

where $L p=$ hydraulic permeability and $P_{\text {net }}=$ net ultrafiltration pressure. Net ultrafiltration pressure (or effective filtration pressure) is the difference across the capillary loop.

$$
P_{\text {net }}=\Delta P-\Delta \Pi=\left(P_{G C}-P_{B C}\right)-\left(\Pi_{G C}-\Pi_{B C}\right)
$$

where $P$ is hydraulic pressure, $\Pi$ is the colloid oncotic pressure, and the subscripts $\mathrm{GC}$ and $\mathrm{BC}$ refer to the glomerular capillaries and Bowman's space. Changes in the glomerular filtration rate are most often a consequence of changes in net ultrafiltration pressure. One factor influencing the net ultrafiltration pressure is the resistance in the afferent and efferent arterioles. An increase in the resistance in the afferent arteriole will decrease the pressure in the glomerular capillaries, and thereby GFR. An increase in the resistance of the efferent arteriole will increase pressure in the glomerular capillaries, and GFR.

GFR is measured by determining the urinary excretion of a marker substance which meets the requirement that the amount filtered per minute is equal to the amount excreted in urine per minute. This requirement is met with a substance such as inulin which is neither absorbed nor secreted by the renal tubules, is freely filterable across the glomerular membranes, and is not 
metabolized or produced by the kidneys. Inulin is a large sugar molecule with a molecular weight of about 5000 . In experimental studies it is intravenously infused to determine GFR, which can be calculated using the concentration of inulin in the plasma $\left(P_{\text {in }}\right)$ and urine $\left(U_{\text {in }}\right)$, and urine flow rate $(V)$ with the following equation:

$$
\mathrm{GFR}=U_{\text {in }} / P_{\text {in }} \times V
$$

\section{Renal Plasma Flow}

Kidneys receive just under $25 \%$ of the cardiac output. The glomerular filtrate is formed by filtration of the renal plasma flow (RPF). In order to measure the RPF a solute is needed that is not only filtered, but is actively secreted into the tubule by the tubular epithelial cells so as to be completely eliminated from the blood supply to the renal tubule. Para-aminohippuric acid (PAH) is essentially eliminated in this fashion from the blood. RPF can be calculated by dividing the concentration of $\mathrm{PAH}$ in the urine by the PAH in the plasma and multiplying this by the urinary flow rate $(V)$.

$$
\mathrm{RPF}=\mathrm{U}_{\mathrm{PAH}} / \mathrm{P}_{\mathrm{PAH}} \times \mathrm{V}
$$

\section{Filtration Fraction (FF)}

Filtration fraction (FF) is the fraction of plasma reaching the glomerulus that is filtered. It is calculated by dividing the glomerular filtration rate by the 
renal plasma flow.

$$
F F=G F R / R P F
$$

GFR is the sum of the filtration rates for each of approximately 34,000 nephrons. Thus

$$
\text { GFR }=N \times \text { SNGFR }
$$

where $\mathrm{N}$ is the number of nephrons and SNGFR is the single nephron GFR. SNGFR is defined by the following:

$$
\text { SNGFR }=K_{F} \times P_{U F}=A \times P \times(\Delta P-\Delta \pi)
$$

where $\mathrm{K}_{\mathrm{F}}$ is the glomerular ultrafiltration coefficient [the product of glomerular capillary surface area $(A)$ and its hydraulic permeability $(P)]$, and $P_{U F}$ is the net ultrafiltration pressure (the difference between the mean transcapillary hydrostatic $(\Delta \mathrm{P})$ and colloid osmotic $(\Delta \pi)$ pressure gradients).

The glomerular filtrate undergoes a series of modifications in the remainder of the nephron before becoming the final urine. These changes involve the reabsorption and secretion of solutes and fluids. Reabsorption is the movement of solute and water from the tubular lumen to the blood, and is 
the predominant process in the renal handling of sodium, chloride, water, bicarbonate, glucose, amino acids, protein, phosphate, calcium, magnesium, urea, and uric acid. Secretion is the movement of solute from the blood or cell interior to the tubular lumen, and is important in the renal handling of hydrogen, potassium, and ammonium ions and a number of organic acids and bases.

Substances can move into or out of the tubule by either the transcellular pathway, which requires traversing the luminal and the basolateral cell membranes, or the paracellular pathway between cells. Many specialized membrane proteins participate in the movement of substances across cell membranes along the renal tubule.

\section{Proximal tubules (PT)}

The proximal tubules reabsorb the bulk of filtered small solutes. These solutes are present in proximal tubular fluid in the same concentration as in plasma. Approximately $60 \%$ of the filtered sodium, chloride, potassium, calcium and water and more than $90 \%$ of the filtered bicarbonate are reabsorbed along the proximal tubule. The proximal tubule also reabsorbs nearly all of the filtered glucose and amino acids by sodium-dependent cotransport.

\section{Loop of Henle}

The loop of Henle is important for generation of a concentrated medulla 
and for the dilution of urine. The mechanisms for this are described below:.

The tubular fluid is iso-osmotic when it leaves the proximal tubule and when leaving the loop of Henle, and when it reaches the distal convoluted tubule it is hypo-osmotic to the body fluid. The distal convoluted tubule is low in water permeability and controls the active reabsorption of sodium and passive reabsorption of chloride and water. This takes place under the influence of aldosterone, which stimulates the reabsorption of sodium. As sodium is reabsorbed, potassium is secreted.

The loop of Henle establishes a solute gradient that allows for the high osmotic concentration in the medulla. With the high osmotic concentration of the medulla a high volume of water can be reabsorbed from the collecting duct in the presence of vasopressin to make a hyperosmotic urine. Vasopressin regulates the water permeability of the distal portions of the nephron, particularly the collecting duct. The binding of vasopressin causes the appearance of water channels within the apical membrane of the collecting duct resulting in up to a 20 -fold increase in water permeability.

The rate of fluid reabsorption in a given nephron segment is determined by the magnitude of this gradient and the osmotic water permeability of the segment. If vasopressin is present, the collecting duct becomes water permeable, and water is reabsorbed until the tubular fluid in the collecting duct equilibrates with the hypertonic interstitium. The final urine in this case is 
osmotically concentrated and has a low volume.

\section{Counter current multiplier}

The generation of the unique extracellular hypertonic environment to allow for this concentration of urine is achieved by the countercurrent multiplication system of the renal medulla. There is a countercurrent arrangement of descending and ascending limbs of the loops of Henle. The loops of Henle generate an osmotic gradient because there is active sodium transport across the ascending limb generating an osmotic difference between the tubular fluid and the surrounding interstitium. The low water permeability of the ascending limb prevents the dissipation of this gradient, and the high water permeability of the descending limb permits the equilibration of the descending limb contents with the surrounding local interstitium. As filtrate flows up the ascending thick segment of the loop of Henle, sodium leaves the tubule and the osmotic concentration declines within the tubule, while the adjacent interstitial osmotic concentration rises. The fluid passing down the descending thin limb will equilibrate with this rising interstitial concentration, and water is osmotically withdrawn from the tubule into the medullary interstitium, concentrating the osmolarity of the intratubular fluid as it descends toward the tip. This increasing concentration of the descending tubule causes more sodium loss from the ascending tubule, thus establishing a tubular and interstitial osmotic gradient. 
About half of the inner medullary tonicity is accounted for by urea. Urea enters the medulla by reabsorption across the collecting duct. Because of the varied permeability of the collecting duct to urea and the increasing concentration of urea in the collecting duct with the absorption of water, a substantial urea gradient develops which provides the driving force for urea resorption when the permeability to urea permits it.

\section{Hormonal Regulation}

A change of extracellular fluid volume is sensed by stretch receptors on blood vessels. A decreased firing rate in the afferent nerves from these volume receptors, in the case of lower blood volume, enhances sympathetic outflow from the cardiovascular medullary centers. This increased renal sympathetic tone enhances the renal proximal tubular salt reabsorption, decreases renal blood flow and GFR at high frequencies, and stimulates the renin-angiotensin system (RAS).

A number of hormones interact to control volume and sodium excretion. Atrial natriuretic factor (ANF) secretion increases in volume expansion and is inhibited in volume depletion. ANF causes a natriuresis by inhibition of sodium reabsorption along the collecting duct and under some conditions by causing an increase in GFR.

Vasopressin is regulated mostly by body fluid osmolarity, but vasopressin release set points can be shifted for intravascular volume 
depletion. This allows for water retention to aid in restoration of body fluid volumes.

Renin is an enzyme formed and secreted by the granular cells in the juxtaglomerular apparatus. The action of renin is the proteolytic cleavage of angiotensin I (Ang I) from angiotensinogen (renin substrate), a large circulating protein. Ang $\mathrm{I}$ is a decapeptide which is converted by the angiotensin converting enzyme (ACE) to the biologically active angiotensin II (Ang II). Renin is the rate limiting step in the production of Ang II. Several mechanisms control renin release.

The macula densa, in the juxtaglomerular apparatus (JGA), is a plaque of distinct epithelial cells in the wall of the thick ascending limb of the loop of Henle at the point where the tubule makes contact with its own glomerulus. A decrease in tubular sodium concentration at the macula densa strongly stimulates renin secretion, whereas an increase inhibits it. A decrease in arterial pressure in the afferent arteriole is detected by a baroreceptor and stimulates the secretion of renin. An increase in renal sympathetic activity or in circulating catecholamines stimulates renin release through $\beta$-adrenergic receptors on the juxtaglomerular granular cells.

Ang II promotes salt retention via a number of mechanisms. It stimulates sodium reabsorption in the proximal tubule. Ang II stimulates the production and release of the steroid hormone aldosterone from the zona 
glomerulosa of the adrenal gland. Aldosterone acts on the collecting duct to augment salt reabsorption. In addition, Ang II is a potent vasoconstrictor. The renin-angiotensin system will be covered in more detail in the following pages.

\section{Aging Kidney}

Aging is a biological process which results in the gradual loss of functioning cells from many organs and tissues.

\section{Anatomy}

The kidney experiences renal functional and structural deterioration with aging. Progressive loss of renal mass occurs with aging. This loss takes place largely in the cortex and is associated with a reduction in the number of glomeruli. The incidence of sclerotic glomeruli increases to nearly $40 \%$ in humans by the age of 80 (2). Two patterns of aging have been observed: 1) hyalinization and collapse of the glomerular tuft are associated with the obliteration of the lumen of the pre-glomerular arteriole and a resultant loss in blood flow; and 2) in the juxtamedullary area, there is the development of anatomic continuity between the afferent and the efferent arterioles during glomerular sclerosis, thus leading to the loss of glomerulus and the shunting of blood flow from the afferent to efferent arterioles.

The glomerular basement membrane folds and thickens, condensing into hyaline material along with the glomerular tuft collapse. There is a decrease in glomerular lobulation and a decrease in total surface area and a 
decrease in overall GFR. The glomerular basement membrane loses its charge and becomes more permeable to macromolecules. Thus, proteinuria often signifies the development of glomerular sclerosis.

\section{Function}

Glomerular filtration rate (GFR) has been shown to decline with age but not consistently (17). Renal blood flow (RBF) also declines. The decrease in RBF has been associated with significant increases in both the afferent and efferent arteriolar resistances. This increase in the efferent arteriolar resistance may in part explain the age-related increase in filtration fraction (17, 28). However, other studies have shown an age related decrease in afferent arteriolar resistance (2). Studies have shown that there is an age-related linear reduction in mean blood flow per gram of kidney weight. These also showed a parallel reduction in mean renal blood flow rate (28).

Studies in rats have shown a blunted vasodilation response in the aged model $(2,12,28)$. Vasoconstriction has also been postulated to be exaggerated in the aging model, which may mediate the age-related decrease in RBF and GFR (43).

\section{Possible mechanism}

It has been proposed that there is a relationship between the agerelated increase in filtration fraction to the increased prevalence of glomerulosclerosis. Studies have suggested that the age-related loss of 
glomerular function is not a universal phenomenon, and that dietary, metabolic, hormonal, or hemodynamic factors may play a major role in modulating the age-related decrease in renal function. Hyperfiltration has been suggested as propagating glomerulosclerosis in the aging kidney (4). This theory has been experimentally investigated through a rat nephrectomy model $(28,4)$.

Under increased glomerular capillary pressure $\left(P_{G C}\right)$ seen with aging there is a reduced number of nephrons which further contribute to increased glomerular pressure and thus flow. This cycle is further exacerbated by systemic hypertension, diabetes and chronic renal disease which are often found with aging. The further increasing $P_{G C}$ causes cell injury, permeability changes in the glomerular basement membrane, and glomerular hyperfiltration, which leads to glomerular sclerosis.

The high protein content of the Western diet has been suggested to participate in the functional and structural deterioration of the aging kidney. Studies in dogs and humans have shown a rise in GFR and RBF following a meat meal $(34,42,8,6)$. This after-meal increase in renal blood flow is unrelated to dietary intake of carbohydrates and fats which have little effect on renal structure or function. A continuous protein-rich diet is proposed to cause a sustained increase in blood flow and filtration rate which leads to renal hypertrophy and eventually glomerular sclerosis $(41,42)$. 
A possible mechanism of hyperfiltration promoting glomerular sclerosis in the aging kidney is as follows. In a health young rat kidney, SNGFR for the entire glomerular population are represented by a narrow Gaussian (normal) distribution. The glomeruli at the upper end of the function scale, which have the highest SNGFR values, are thought to be burdened due to the adaptive increases in pressures and flows which lead to hyperfiltration. These now overburdened glomeruli will eventually fail and cause the remaining glomeruli to hyperfilter to accommodate the high protein diet with the now reduced nephron population. Thus the nephron population has both poorly functioning nephrons and hyperfiltering nephrons. The SNGFR population still shows a Gaussian distribution with the average SNGFR the same, and total glomerular filtration rate remaining at $100 \%$, but has both poorly functioning nephrons and hyperfiltering nephrons. However, all glomeruli are now at risk in that the lowflow nephrons have already been injured by high hydraulic pressures, and the hyperfiltering nephrons have, by definition, high pressure and flow. Part of the glomerular population will eventually stop functioning with an SNGFR of zero, and the remaining nephrons will have an SNGFR below normal, leaving the total GFR at $50 \%(4)$.

The above process is greatly accelerated when the functioning nephron number is abruptly reduced by acute renal disease, as seen with systemic diseases such as atherosclerosis, hypertension, cardiac failure, diabetes 
mellitus and malignancies which plague the aging with high frequency. Experimentally this compounded process can be represented by surgical removal of renal tissue as is done in a uninephrectomy. The removal of tissue results in an increase in the perfusion and filtration of the remaining nephron units, which causes structural and functional hypertrophy in a fashion beyond what is due to aging alone. These glomerular changes in the remaining kidney are morphologically identical to those seen in the aging kidney with the difference being the rate of glomerular structural deterioration. The consequences of uninephrectomy are a rapidly transformed population of glomeruli, with half of the nephrons having a single nephron glomerular filtration rate (SNGFR) of zero and the remainder hyperfiltering, yielding a total GFR of approximately $70 \%$ of normal. Hyperfiltration results in the destruction of this remaining half, which later leads to a total of $20 \%$ normal GFR (4).

Lowering the glomerular capillary pressure and flow by lowering protein dietary protein or salt restriction prevents the progressive sclerosis of the remaining kidney in rats with reduced renal mass (22). Dietary protein restriction also slows the pace of glomerular sclerosis with aging (30). As this model of hyperfiltration of a burdened kidney has been observed in many pathologic studies in renal disease, protein restriction has retarded the development of renal pathology in many of these diseases including aging (4). 
The treatability of these diseases with protein restriction is consistent with the hyperfiltration model as detrimental to glomerular structure and function.

\section{Sodium handling}

Sodium handling is altered with age. Both the excretory capacity for sodium and the circadian variation in excretion are influenced by age. The age-related decrease in GFR has been proposed to be a factor which limits the ability of the aged kidney to excrete an acute sodium load (28). Older subjects have been found to take twice the time of young to lower their sodium excretion during a sodium restricted diet (17). Studies have shown that sodium handling by the proximal convoluted tubule is normal, but that the reabsorption in the ascending loop of Henle is impaired, thus increasing the sodium delivered to the distal segments and the medullary interstitium, and decreasing ability to concentrate the urine (31). Plasma renin levels, and blood and urinary aldosterone levels, are significantly reduced in the elderly population, blunting the response to a stimulus such as sodium restriction. Investigations have also shown an impaired ability to excrete excess sodium for various reasons (28).

\section{Renin-angiotensin system (RAS)}

The renin-angiotensin system (RAS) is a ubiquitous intracrine, autocrine and paracrine hormone system. The RAS is widely believed to have two facets: the circulating RAS and the local tissue RAS. The circulating RAS 
is postulated to provide short term cardiorenal homeostasis by acutely protecting the blood pressure, blood flow and maintenance of sodium and water homeostasis. The local tissue RAS maintains tonic control of tone, vascular resistance, flow, local tissue function, regulation of body fluid volume, sodium transport, and modulation of the sympathetic nervous system and cardiovascular structure $(15,26)$.

In the RAS cascade, the enzyme renin cleaves angiotensinogen, secreted by the liver, to form angiotensin I (Ang I), which is then cleaved by angiotensin converting enzyme (ACE) to form angiotensin II (Ang II). The traditional view of the circulating RAS is that the enzyme renin is secreted by the kidney into the circulation and then acts on angiotensinogen to make Ang I. Ang $I$ is acted upon by ACE which is ubiquitous to the cells and tissues of the body. Ang II is best known for renal homeostasis and cardiovascular function, but it has many target organs. The role of the circulating RAS has been addressed by inhibiting this system. Conditions with high renin levels such as sodium depletion and hypertension treated with a blockade of the RAS result in acute depressor response.

The presence of local tissue RAS adds additional dimension to this omnipresent system. It is indicated by the demonstration of renin-like enzymatic activity, renin substrate, ACE, angiotensins, and angiotensin receptors in multiple tissues. These compounds have been identified by both 
biochemical and immunohistochemical studies. Furthermore, molecular biologic techniques have shown that renin and angiotensinogen mRNAs are expressed in those major organs that play important roles in cardiorenal homeostasis such as the blood vessels, kidney, adrenals, brain and heart.

The intracellular synthesis of the angiotensins has been studied in cell culture. Multiple scenarios have been submitted for Ang II production. These include the intracellular production and secretion of Ang II, the synthesis and secretion of Ang I converted by extracellular ACE to Ang II, and the separate production of renin and angiotensinogen by different cells within a system to provide for the extracellular production of angiotensins (15).

Renin is considered to be the rate limiting step in the enzymatic cascade of the RAS. When ACE is inhibited it becomes the rate limiting step. ACE is a zinc metalloenzyme with two active catalytic sites with different conformational requirements. ACE has multiple substrates: Ang I, bradykinin, enkephalin, neurotensins, cholecystokinin, gonadotrophin, and luteinizing hormone-releasing hormone. Inhibition of ACE has acute hypotensive effects, including the inhibition of the RAS. Converting enzyme inhibition (CEI) inhibits the vasoconstrictive effect of Ang II but will also inhibit the stimulation of aldosterone and therefore salt homeostasis, as well as altering the kallikreinkinin and bradykinin systems. Different ACE inhibitors also block the bioactivity of ACE at the respective catalytic sites. Thus it is not surprising that 
the ACE concentration and drop in blood pressure do not always correlate well with the dose of CEI $(25,26)$.

\section{Vascular RAS}

The vasculature holds RAS components and ACE in all of its layers with some variation depending on the specific location of the vessel. Ang II receptors have been found throughout the smooth muscle layer of the vasculature. Angiotensin is known to be a regulator of noradrenaline release from sympathetic nerve terminals and thus may modulate local sympathetic activity. Ang II further interacts with endothelial and smooth muscle cells and maintains vascular tone. Ang $\|$ has been shown to initiate the release of prostaglandins and endothelium-derived relaxing factor (nitric oxide) from endothelial cells in culture. Ang II may have a role in inflammation, hyperplasia, and hypertrophy. The action of the vascular RAS is thought to involve the regulation of vascular tone and blood flow, pathogenesis of chronic hypertension, determination of response to RAS inhibitors.

\section{Other tissue RAS}

The cardiac RAS is thought to involve vasoconstriction, increased contractility, stimulation of myocyte growth, myocardial metabolism and a role in ventricular arrhythmias. The adrenal RAS is correlated with the secretion of aldosterone and catecholamines. The brain RAS may be involved in thirst, behavior, blood pressure, vasopressin and catecholamine release. 


\section{Renal RAS}

The kidney RAS controls distribution of renal blood flow; regulation of GFR through arteriolar contraction, ultrafiltration coefficient, and mesangial contraction; sodium reabsorption by PT; the renal concentrating mechanism; potentiation of renal sympathetic activity; modulation of mesangial cell function; and a role as a renal growth promoter. All of the components of the RAS are present in the fetal and adult kidney. The measured Ang II levels in lymph, proximal tubule fluid, and renal tissue are all of a significantly higher concentration than the plasma levels, which is a strong indication for the intrarenal production of Ang II. The importance and function of the intrarenal RAS as distinguished from the circulating RAS is controversial, but increasing evidence suggests that it plays an important role.

Although widely distributed in the fetal kidney throughout maturation, renin becomes isolated in the afferent arteriole until it is found primarily in the juxtaglomerular apparatus (JGA) of the adult kidney. Renin mRNA has been identified in the distal afferent arteriole, the glomerulus and in the efferent arteriole. Renin release is stimulated by an increase in cAMP production and inhibited by increases in cytosolic calcium. The four main stimuli for renin release from the JGA are: 1) concentration of sodium chloride at the macula 
densa, 2) the sympathetic nervous system, 3) hormones such as intrarenally produced Ang II, adenosine, atrial natriuretic factor (ANF), and 4) a decrease in intrarenal blood pressure. Some pathophysiological conditions that exhibit alterations in renin release and renin gene expression are diabetes mellitus, high protein feeding, ureteral obstruction, and polycystic kidney disease (11).

The largest renal concentration of angiotensinogen mRNA is located in the proximal tubules(PT). This level is much lower than that found in the liver. There is an increase in kidney angiotensinogen mRNA with sodium chloride depletion, while hepatic angiotensinogen shows no changes (11).

ACE is found throughout the kidney but the largest concentration is in the PT. Not much is known about ACE regulation in the PT. Fox et al. (19) found that whole kidney ACE levels increased with decreased salt intake, and that renal ACE activity was only reduced by $58 \%$ by a dose of the inhibitor enalaprilat while plasma ACE activity was reduced by $100 \%$. Angiotensin converting enzyme inhibitors (CEI) have been helpful in isolating the role of angiotensin II in renal function. Some of the effects of ACE inhibition on renal function are attributable to the drop in blood pressure as well as to the inhibition of the intrarenal Ang II production. A dose dependent and time responsive inhibition of renal $A C E$ has been observed with $C E I$. Administration of CEI causes variable effects on GFR: a reduction due to decreased $P_{G C}$, but increases due to increased renal plasma flow (RPF) and 
ultrafiltration coefficient. In conscious animals where the kidney is least renin dependent, a fall in GFR could be more attributable to direct effects of Ang II on the efferent arteriole and glomerular capillary pressure $\left(P_{G C}\right)$ but again, it is counteracted by the increase in $\operatorname{RPF}(2,7)$.

While the $A T_{2}$ angiotensin receptor is found throughout the fetal kidney, the angiotensin $A T_{1}$ receptor is predominant in the adult kidney and can be considered to be responsible for most Ang II action. The placement of the $A T_{1}$ receptors on both the arterioles and mesangial cells of the glomerulus is consistent with the premise that Ang II regulates glomerular microcirculation by the afferent and efferent arterioles and modulates the glomerular capillary ultrafiltration coefficient. [Ang II is thought to act largely on the efferent arteriole with norepinephrine working on both arterioles.] Ang II effects on the arterioles are eliminated in experiments in with removal of the glomerulus and distal afferent arteriole, which suggest that the juxtaglomerular apparatus (JGA) and the glomerulus may play a role in the afferent contraction. Ang II binds with the $A T_{1}$ receptors on the mesangial cells of the glomerulus causing them to contract and lower the glomerular capillary surface area. These receptors may be linked to the ultrafiltration coefficient and play a role in mesangial sieving and thus selectivity to size and charge of molecules. There is an inverse relationship among local and plasma Ang II concentrations and the number of glomerular Ang II receptors. $\mathrm{AT}_{1}$ receptors are increased with 
salt loading and decreased with salt restriction (11). Ang II receptors are found in the tubule segments but mostly in the PT.

\section{Proximal tubule RAS}

The renal RAS is located in the proximal tubules (PT); all of the RAS components are found there. Several studies have found renin synthesis (i.e. mRNA) within the PT cells(11). Ang II may regulate PT function. PT fluid has an Ang II concentration that is much higher than plasma Ang II, suggesting that Ang II is released pre-formed into the lumen from the PT cells, that there is an intraluminal generation of Ang II by apical membrane ACE on Ang I, or that there is release of Ang II from the proximal interstitium. It seems unlikely that the Ang II found in the kidney is from the plasma filtrate, because PT levels exceed those in plasma, and exogenous Ang II is degraded by the PT brush border peptidase.

Alterations in the circulating and renal renin angiotensin system(RAS) are hypothesized to play a role in the pathogenesis of renal disease in the aging rat. The following study investigates the presence of age related changes in the activity and responsiveness of the RAS in the 15 month old compared to the 3 month old rat. Systemic and renal function and biochemical measurements were measured in the untreated animals and in rats receiving the angiotensin converting enzyme inhibitor, enalapril. 


\section{METHODS}

The aging model. Studies were conducted in adult male SpragueDawley rats (Harlan, Indianapolis) at two time points: young (age 3 mos) and older (15 mos). The age of 15 months was chosen because it is considered a transition or "middle age" where glomerular injury is apparent but not overt. All rats were fed standard rat chow (Rodent Laboratory Chow 5001, Purina Mills, Richmond, IN) ad libitum, and had free access to water. Baseline studies assessed awake systolic blood pressure (SBP), by the tail cuff method, and metabolic cage studies for 24-hour urinary collections for the measurement of total urinary protein excretion $\left(U_{\text {prot }} V\right)$. Thereafter rats were given four weeks of the CEI enalapril (Sigma, St. Louis, MO) at a low dose of $100 \mathrm{mg} / \mathrm{L}$, or a high dose of $150-200 \mathrm{mg} / \mathrm{L}$, in drinking water. An untreated group was maintained as a control. The low dose rats received $100 \mathrm{mg} / \mathrm{L}$ enalapril which caused systolic blood pressure (SBP) to fall approximately 10 $\mathrm{mmHg}$ in both young and older rats. The high dose of $150 \mathrm{mg} / \mathrm{L}$ for the young, and $200 \mathrm{mg} / \mathrm{L}$ for the older, were chosen after pilot studies established that these doses resulted in SBP reductions of approximately $20 \mathrm{mmHg}$. After four weeks of treatment SBP measurements and metabolic cage studies were repeated. Thereafter, Protocol 1 involved renal functional studies with measurement of glomerular filtration rate(GFR), renal plasma flow (RPF) and filtration fraction (FF). Protocol 2 assessed the left kidney and blood Ang II 
levels as well as the plasma renin concentration (PRC). These studies were approved by the Portland Veterans Affairs Institutional Animal Care and Use Subcommittee.

\section{Protocol 1: Renal Function}

Surgical Preparation. All rats were anesthetized with Inactin (100 $\mathrm{mg} / \mathrm{kg}$ i.p.) and placed on a thermoregulated table. The left femoral artery was cannulated and a baseline sample of blood was collected for determination of hematocrit (Hct), and inulin and para-aminohippurate (PAH) blanks. This arterial catheter was used for subsequent blood sampling and for the estimation of mean arterial pressure (MAP) via an electronic transducer connected to a direct writing recorder. After tracheostomy, bilateral internal jugular catheters were inserted for infusions of rat serum, and $10 \%$ inulin (Isotex) with $0.8 \% \mathrm{PAH}$ in $0.9 \% \mathrm{NaCl}(1.2 \mathrm{ml} / \mathrm{h})$. The left ureter was catheterized for urine collections.

To maintain euvolemia, rat serum was infused at $0.1 \mathrm{ml} / \mathrm{min}$ for a total equal to $1 \%$ of the body weight, followed by a reduction in infusion rate to $0.007 \mathrm{ml} / \mathrm{min}$ for young rats and $0.012 \mathrm{ml} / \mathrm{min}$ for older rats, to maintain a constant Hct. After equilibration, triplicate 20 minute urine collections with midpoint blood collections were made, for measurement of inulin and PAH clearances. Blood was obtained simultaneously for measurement of Hct, 
inulin, and PAH. Glomerular filtration rate (GFR) from inulin clearance, renal plasma flow (RPF) from PAH clearance, and FF were determined using standard formulas. Mean arterial pressure (MAP) was also recorded during each collection period.

\section{Protocol 2: Short-term anesthesia studies}

The RAS has long been recognized to be activated by prolonged anesthesia and surgery (35). To minimize RAS stimulation, rats were anesthetized for under 10 minutes prior to taking kidney tissue and blood samples. Rats were anesthetized with Inactin (100 mg/kg ip) and placed on a thermoregulated table. The left kidney was quickly excised and homogenized in cold methanol for Ang II measurement. Blood was rapidly obtained by cardiac puncture into prechilled syringes and separated into tubes of either cold methanol (for Ang II) or $4.5 \mathrm{mg}$ EDTA (for determination of plasma renin concentration(PRC)).

\section{Biochemical studies}

For the calculation of GFR, inulin concentrations in plasma and urine were determined by the macro-anthrone method. RPF was determined by $\mathrm{PAH}$ clearance. PAH concentrations in plasma and urine were determined by colorimetric methodology. Plasma renin concentration (PRC) was measured in plasma collected by cardiac puncture. PRC was measured by incubating 
$100 \mu \mathrm{l}$ of rat plasma with $100 \mu \mathrm{l}$ rat anephric plasma and $400 \mu \mathrm{l}$ of $0.2 \mathrm{M}$ maleate buffer, $\mathrm{pH} 6.0$ at $37^{\circ}$ for $1 \mathrm{hr}$. Appropriate dilutions of rat plasma samples were made using Tris buffer. The generation of Angiotensin I (Ang I) was then determined by radioimmunoassay using commercially available reagents (New England Nuclear, Boston, MA). Ang I levels generated were taken as indicative of the amount of renin present.

Ang II was measured using methods established by Fox, et al. (19). Briefly, one $\mathrm{ml}$ of blood and weighed kidney samples were immediately placed in glass tubes containing $100 \%$ methanol at $4^{\circ} \mathrm{C}$ (total volume $10 \mathrm{ml}$ ); kidneys were rapidly homogenized, and the samples were centrifuged at $4^{\circ} \mathrm{C}$ for 15 minutes. The resulting supernatant was then dried under vacuum overnight (Speed Vac, Savant), and resuspended in assay diluent $(6 \mathrm{ml}$ of $50 \mathrm{mM}$ $\mathrm{NaPO}_{4}, 1 \mathrm{mM}$ EDTA, $0.25 \mathrm{mM}$ thimerosal and $2.5 \mathrm{mg}$ heat-inactivated $\mathrm{BSA} / \mathrm{ml}, \mathrm{pH}$ 7.4) before organic extraction on phenyl-bonded SPE columns (Bond-Elut, Varian, Harbor City, CA). Columns were prewashed with methanol and water. After samples were applied the columns were sequentially washed with water, hexane and chloroform. After elution with $90 \%$ methanol, extracted samples were again dried under vacuum and resuspended in assay buffer prior to radioimmunoassay. Ang II was quantified in a competitive single antibody radioimmunoassay, using rabbit anti-Ang II antibody (Peninsula, Belmont, CA) and monoiodinated $\mathrm{I}^{125}$ labeled Ang II (Amersham, 
Arlington Heights, IL) and Ang II standards (Sigma). Each assay tube contained assay diluent $(100-400 \mu \mathrm{l})$, sample $(50-300 \mu \mathrm{l})$, antiserum in diluent $(0$ or $100 \mu \mathrm{l})$, and radiolabel in diluent $(100 \mu \mathrm{l})$. Each lyophilized antiserum was diluted sufficiently to yield a specific binding of $35-40 \%$ after incubation with 3000 counts/min label for two days. After an incubation period of 2 days at $4^{\circ} \mathrm{C}$, bound and free Ang peptides was separated with dextran-coated charcoal. The supernatant was then decanted and counted, and the bound peptide/non-bound peptide determined. Ang II samples were assayed in duplicate, and values were plotted against a curve generated from Ang II standards (Sigma). The sensitivity of this assay has been enhanced to allow detection of low levels of Ang II. The detection limit is $0.5 \mathrm{fmol} / \mathrm{tube}$. Nonspecific binding determined in tubes containing no antiserum was routinely $<3 \%$. The antibody shows the following \% cross-reactivity: Ang II, 100\%; Ang III, 100\%; Ang I, 0.5\%; Ang-(3-8), $77 \%$ (with less displacement of ${ }^{125}$ I than that of Ang II). Our intra-assay coefficient of variation was 3\%; the interassay coefficient of variation was $14 \%$.

Urinary total protein content was measured by the use of $3 \%$ sulfosalicylic acid precipitation.

Statistics. Values are reported as means \pm SEM. Statistical analysis was performed by two-way analysis of variance. Normality was assessed using the Shapiro-Wilk statistic and homogeneity of variance was tested with 
Hartley's $F_{\max }$ test. Values which were not normally distributed or homogeneous in variance were analyzed using the nonparametric KruskalWallis test. Statistical significance was defined as $p<0.05$. The statistical programs used were SPSS and SAS. $(37,38,39)$. 


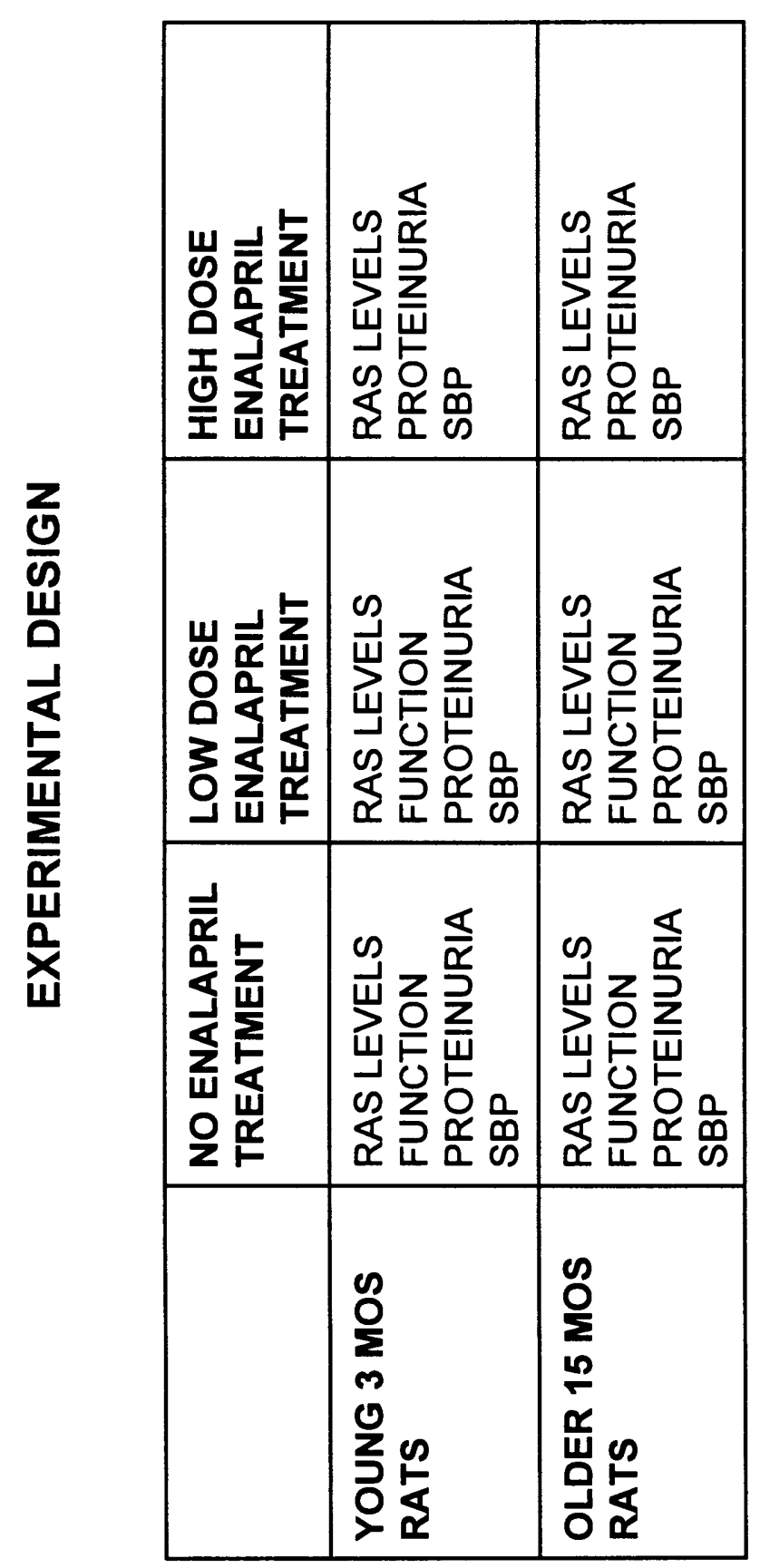




\section{RESULTS}

Pooled systolic blood pressure (SBP) results for older and young rats are depicted in Tables 1 and 4 . Both older and young rats were normotensive at baseline. Enalapril treatment caused a parallel decline in systolic blood pressure in both older and young rats $(p<0.0001)$. The baseline urinary protein excretion $\left(U_{\text {prot }} V\right)$ was higher in older rats than in the young rats $(61 \pm$ $8 \mathrm{mg} /$ day vs. $7 \pm 1 \mathrm{mg} /$ day; $p<0.0001)$ and continued to be so throughout treatment (Tables 1 and 4). Proteinuria suggests the presence of moderate age-related glomerular injury in the older rats $(2,4,43)$. Although the urine protein concentration numerically declined with enalapril treatment in the older rats, significant treatment effect was not found in this four week treatment time.

Older rats were larger than young rats at baseline and throughout treatment $(p<0.0001)$. Enalapril treatment did not alter body mass when these values were pooled. However, treated rats, used for functional measurements, had less mass than their corresponding untreated groups by the end of treatment (data not shown).

\section{Protocol 1. Functional Studies}

Enalapril lowered the mean arterial pressure (MAP) in the young ( $p$ $=0.0027)$ but not the older rats; thus age altered the blood pressure response to converting enzyme inhibition (CEI) $(p=0.0202$; Tables 2 and 5). During the 
experiments, CEI blockade was confirmed by infusing Ang I; suppression of angiotensin converting enzyme(ACE) limits conversion of Ang I to Ang II, and therefore negates the hypertensive effect of Ang I. Enalapril-treated animals showed only a slight $(11 \pm 2 \mathrm{mmHg})$ rise in MAP with Ang I, while untreated animals showed $20 \pm 3.5 \mathrm{mmHg}$ rise with Ang I infusion $(p<0.05)$. Thus, the older rats had successful ACE blockade, despite the absence of a MAP response.

Glomerular filtration rate (GFR) was altered by neither age nor enalapril (Tables 2 and 5). However, GFR declined with age when adjusted for body mass (GFR/100 g BM; $p<0.0001$ ). As body mass increased with age, so did kidney mass $(p<0.0001)$, such that the kidney mass to body mass ratio did not change with age (Tables 2 and 5). Treatment has a slightly significant influence upon the kidney mass/body mass ratio, which may be due to the decline in body mass with treatment. Enalapril did not improve GFR $/ 100 \mathrm{~g}$ BM. Similarly, both age and treatment failed to influence renal plasma flow (RPF), but when adjusted for body mass, RPF declined with age $(p=0.0428$, Tables 2 and 5) and was not improved with enalapril. Age caused a decrease in filtration fraction $(p=0.0370)$ which likewise was not adjusted with enalapril treatment (Tables 2 and 5).

Protocol 2. Renin-angiotensin system biochemical measurements

Enalapril treatment influenced biochemical measurements in the 
expected fashion: increased plasma renin concentration (PRC; $p<0.0001$ ), decreased left kidney (LK) Ang II concentration ( $p<0.0001$ ), and overall decreased blood (B) Ang II concentration ( $p=0.0398$ ). Aging exhibited no influence on any of these parameters in either treated or untreated groups (Tables 3 and 6). 


\section{DISCUSSION}

Age-related proteinuria in rats reflects glomerular sclerosis $(2,43)$ and has been associated with age-related renal disease in humans. This correlation prompted studies to explore dietary protein reduction, and more recently angiotensin converting enzyme inhibition (CEI), to reduce renal injury in the rat model. The Sprague-Dawley rat model develops spontaneous proteinuria and glomerulosclerosis with age. By the age of 15 months, these rats develop moderate proteinuria and glomerular sclerosis, while remaining normotensive (43). Hence, we chose this model and age to test the responsiveness to $\mathrm{CEI}$ during this transition age where progressive renal disease has begun, but is not complicated by systemic hypertension.

Baseline and post-treatment studies of systolic blood pressure (SBP) and proteinuria $\left(U_{\text {prot }} V\right)$ showed that four weeks of enalapril therapy successfully lowered the systolic blood pressure, but failed to reduce proteinuria in the aging rat. Other studies, in aging rats, reported a depressor response with $\mathrm{CEI}$, accompanied by a decline in proteinuria or albuminuria $(2$, 45). However, these studies included a much longer treatment regime of four to twelve months. In one, a significant decline in albuminuria was not reached until two months, although depressor response was apparent at one month (2). Zoja et al. (45) showed a decline in proteinuria after four months of CEI treatment, yet, at one month's time, the decline in proteinuria was less than 
half the four month improvement. Consequently, four weeks may be too short a treatment duration to lower proteinuria in rats already affected by glomerular sclerosis.

Age influenced most functional parameters, but, a decisive alteration of enalapril response, with age, was only evident in mean arterial pressure (MAP). Glomerular filtration rate (GFR) and renal plasma flow (RPF) decreased with age when adjusted for body mass and did not improve with treatment. Young rats also failed to respond to enalapril in these parameters, and therefore in the absence of a positive control, limit us to conclude that older rats do not have an altered renal response to CEI with age. Furthermore, filtration fraction, although decreased with age, similarly did not respond to treatment in either young or older, (though numerically reduced in the older).

A refractory response in mean arterial pressure to enalapril was present in the older, but not the young rats, and initially appeared to support our aging response hypothesis. Corman and Michel (12) found a similar resistance to CEI, in not only mean arterial pressure, but also glomerular filtration rate and renal plasma flow in 30 month old, compared to 20 and 10 month old rats. This lack of vasodilation in the old rat was confirmed by Anderson et al. (2) who observed the failure of CEI to reduce efferent arteriolar resistance in the 30 month old rat. Both investigators ascribe these results to a lack of Ang II- 
dependent vasoconstriction, a consequence of the diminished reninangiotensin system observed with age. Our present study failed to find an age- related decline in biochemical measurements of the renin angiotensin system, and thus cannot attribute the maintained mean arterial pressure in the older treated rat to this mechanism. Furthermore, this pressor response is inconsistent with the decline in systolic blood pressure observed just prior to surgery in the same rats. Anesthesia has been recognized to induce renin release (35), and consequently to raise Ang II concentration. Although Ang II blockade with enalapril significantly reduces Ang II, it does not eliminate this peptide, because there are several pathways of its production (15). Accordingly, the absence of a decline in MAP in the older treated rats, may be an artifact of anesthesia. In this regard, Tank et al. (43) observed an agerelated exaggerated renal response to systemic vasoconstrictor stimuli in the same age (15 months) and strain of rat. Therefore, the older rats may react to vasoconstrictors, released during anesthesia, that the young do not. Additionally, this same study found a preserved responsiveness to Ang II blockade with the angiotensin II receptor antagonist, losartan (43).

The older rats, treated with CEI, had a calculated plasma concentration of $0.198 \mu \mathrm{g} / \mathrm{ml}$ of enalapril, while the young treated rats had $0.210 \mu \mathrm{g} / \mathrm{ml}$. These concentrations exceed those used by Baylis (7), which evoked GFR and RPF increases in the older rats (19-22 months), not apparent in the young 
(3-5 month). Our doses also exceed those of Corman and Michel (12) who found increased GFR and RPF in both 10 month and 20 month old rats, but not 30 month old animals with converting enzyme inhibition. Furthermore, we verified Ang II blockade with Ang I infusion. Hence, the lack in renal functional response to enalapril treatment found in this study is not a consequence of an inadequate CEI dose. Our younger rat age, of 15 months, may contribute to our inconsistency with Baylis (7), while species and gender may differentiate our study from Corman and Michel (12).

Biochemical measurements of the renin angiotensin system failed to reveal age related suppression or response to treatment in either systemic or renal compartments. Accordingly, we conclude that at 15 months, age has not altered renin-angiotensin concentrations or biochemical responses to converting enzyme inhibition in the Sprague-Dawley rat. Decreased plasma renin concentration, with age, has been consistently found in the literature $(5$, $27,12)$, and the absence of this finding, in this study, may indicate that 15 months is too early, in the aging process, to detect an age-related renin alteration, in this strain of rat. Corman and Michel (12) found decreased plasma renin concentration in the 20 month old, but not 10 month old rats, and concluded that the most dramatic age-related changes in the reninangiotensin system occur after 20 months. In one of the few studies which measured blood and kidney angiotensin levels in aging rats (5), blood Ang II 
concentration was observed to decline at 15 months; however kidney Ang II was not found to rise until 24 months of age.

In summary, this study was unable to support our hypothesized depression of response, in 15 month old animals, to the converting enzyme inhibitor, enalapril. Although an age-related decline in function in the older animals was observed and was not improved with treatment, the absence of a positive control response in the young rats prevents a decisive conclusion that the older rats react differently to enalapril. Furthermore in the biochemical data, we found neither an age-related suppression of renin-angiotensin parameters, nor an age-related response to enalapril treatment. Therefore we conclude that neither alterations in response to Ang II blockade, with enalapril, nor age-related alteration of renin-angiotensin hormone concentration, are present at this early stage in aging. 


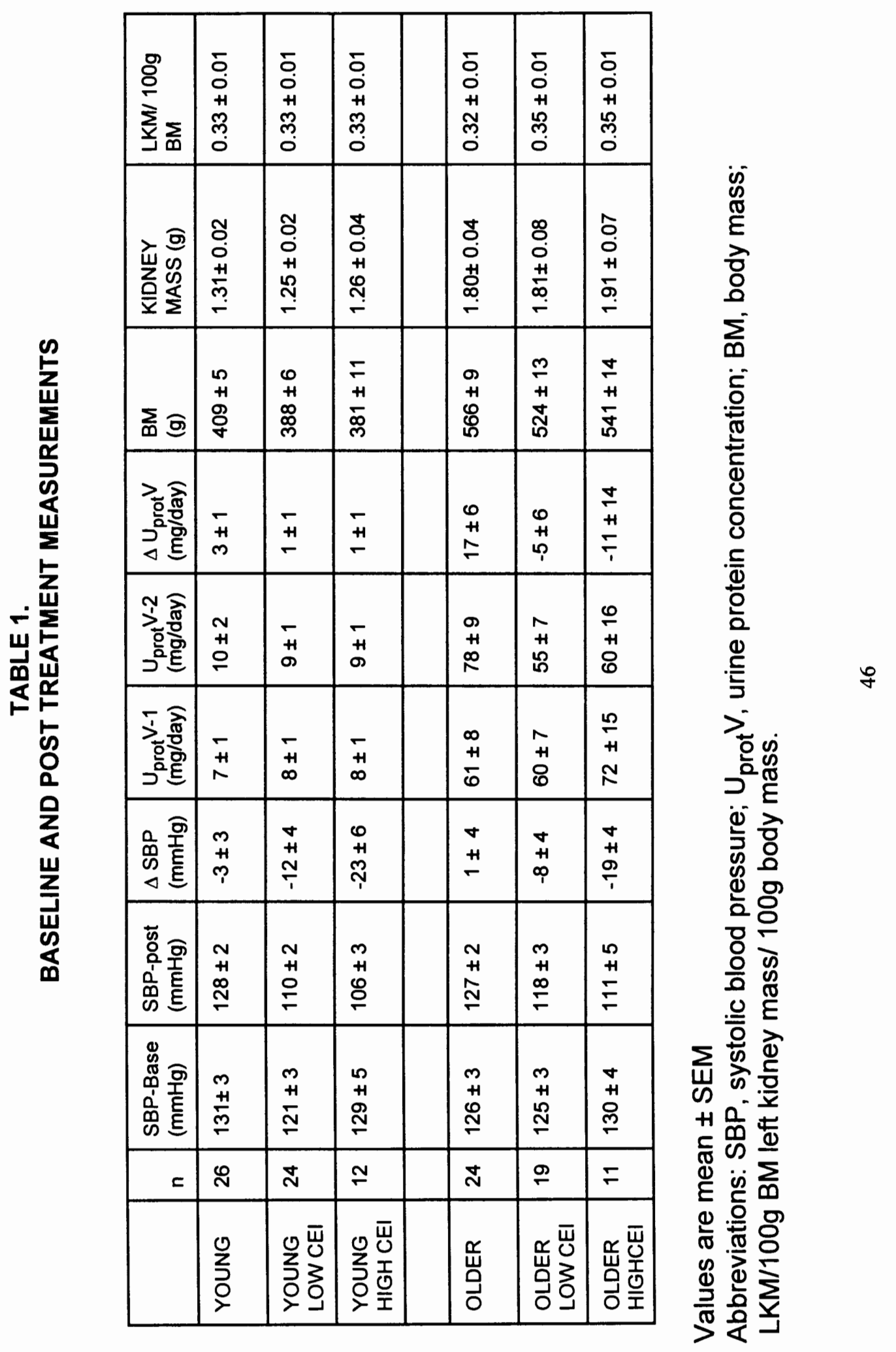




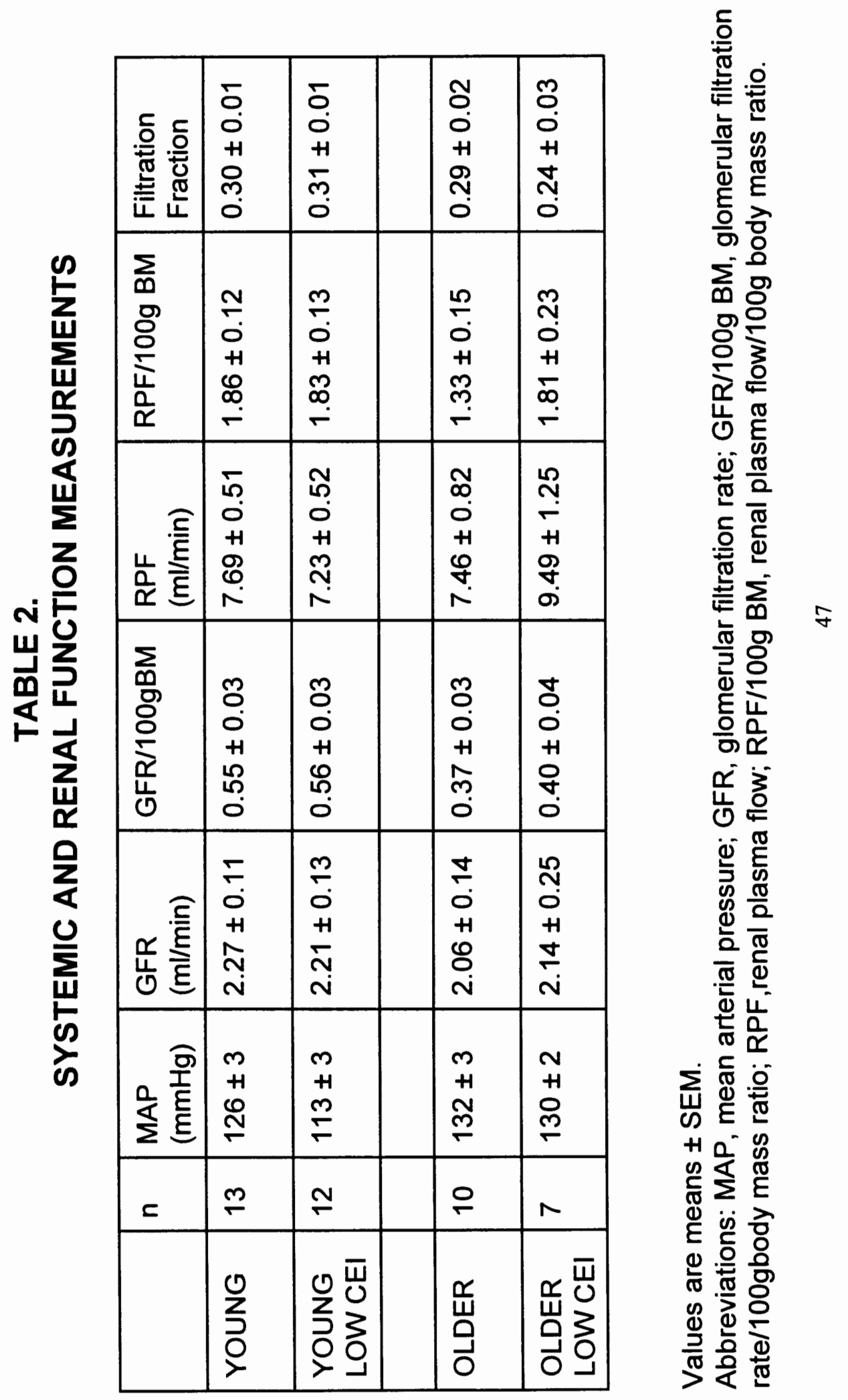


TABLE 3.

RENIN-ANGIOTENSIN SYSTEM MEASUREMENTS

\begin{tabular}{|l|l|l|l|l|}
\hline & $n$ & $\begin{array}{l}\text { PRC } \\
\text { ng Al /ml/min. }\end{array}$ & $\begin{array}{l}\text { LK Ang II } \\
\text { fmol/g }\end{array}$ & $\begin{array}{l}\text { B Ang II } \\
\text { fmol/ml }\end{array}$ \\
\hline YOUNG & 13 & $10.0 \pm 1$ & $63.0 \pm 6.0$ & $8.9 \pm 1.8$ \\
\hline $\begin{array}{l}\text { YOUNG } \\
\text { LOW CEI }\end{array}$ & 12 & $312 \pm 100$ & $37.2 \pm 6.0$ & $\begin{array}{l}14.7 \pm \\
5.7\end{array}$ \\
\hline $\begin{array}{l}\text { YOUNG } \\
\text { HIGH CEI }\end{array}$ & 12 & $261 \pm 47$ & $28.1 \pm 2.2$ & $5.3 \pm 1.8$ \\
\hline & 12 & $8.69 \pm 1$ & $70.5 \pm 5.8$ & $6.5 \pm 1.0$ \\
\hline OLDER & 11 & $154 \pm 33$ & $31.9 \pm 5.1$ & $5.2 \pm 1.1$ \\
\hline $\begin{array}{l}\text { OLDER } \\
\text { LOW CEI }\end{array}$ & 11 & $27.0 \pm 3.4$ & $5.0 \pm 1.2$ \\
\hline $\begin{array}{l}\text { OLDER } \\
\text { HIGH CEI }\end{array}$ & 11 & $362 \pm 87$ & & \\
\hline
\end{tabular}

Values are means \pm SEM

Abbreviations: PRC, plasma renin concentration; LK Ang II, left kidney angiotensin II; B Ang II, blood angiotensin II. 
TABLE 4.

STATISTICAL RESULTS OF BASELINE AND POST-TREATMENT MEASUREMENTS

\begin{tabular}{|c|c|c|c|}
\hline VARIABLE & ASSUMPTIONS & $\begin{array}{l}\text { 2-WAY ANOVA } \\
\text { RESULT } \\
\end{array}$ & $\begin{array}{l}\text { KRUSKAL- } \\
\text { ALLIS RESULT } \\
\end{array}$ \\
\hline $\begin{array}{l}\text { Systolic Blood } \\
\text { Pressure-SBP } \\
\text { baseline }\end{array}$ & $\begin{array}{l}\text { normality } \\
\text { homogeneity of } \\
\text { variance }\end{array}$ & $\begin{array}{l}\text { age NS } \\
\text { treatment NS } \\
\text { age + treat NS }\end{array}$ & NA \\
\hline $\begin{array}{l}\text { Systolic Blood } \\
\text { Pressure-SBP } \\
\text { post treatment }\end{array}$ & $\begin{array}{l}\text { normality } \\
\text { heterogeneity } \\
\text { of variance }\end{array}$ & $\begin{array}{l}\text { age NS } \\
\text { treatment } p<0.0001 \\
\text { age + treat } N S\end{array}$ & $\begin{array}{l}\text { age NS } \\
\text { treatment } \\
p<0.0001\end{array}$ \\
\hline $\begin{array}{l}\text { Blood Pressure } \\
\text { Difference } \\
\Delta \text { SBP }\end{array}$ & $\begin{array}{l}\text { normality } \\
\text { heterogeneity } \\
\text { of variance }\end{array}$ & $\begin{array}{l}\text { age NS } \\
\text { treatment } p<0.0001 \\
\text { age +treat NS }\end{array}$ & $\begin{array}{l}\text { age NS } \\
\text { treatment } \\
p<0.0001\end{array}$ \\
\hline $\begin{array}{l}\text { Urine protein- } \\
\text { UprotV } \\
\text { baseline }\end{array}$ & $\begin{array}{l}\text { non normality } \\
\text { variance } \\
\text { heterogeneity }\end{array}$ & $\begin{array}{l}\text { age } p<0.0001 \\
\text { treatment NS } \\
\text { age + treat. NS }\end{array}$ & $\begin{array}{l}\text { age } \\
p<0.0001 \\
\text { treatment } \\
\text { NS }\end{array}$ \\
\hline $\begin{array}{l}\text { Urine protein- } \\
\text { UprotV } \\
\text { post treatment }\end{array}$ & $\begin{array}{l}\text { non normality } \\
\text { heterogeneity } \\
\text { of variance }\end{array}$ & $\begin{array}{l}\text { age } p<0.0001 \\
\text { treatment NS } \\
\text { age + treat. NS }\end{array}$ & $\begin{array}{l}\text { age } \\
p<0.0001 \\
\text { treatment } \\
\text { NS }\end{array}$ \\
\hline $\begin{array}{l}\text { Difference in } \\
\text { Urine protein } \\
\Delta \text { Uprot } V\end{array}$ & $\begin{array}{l}\text { non normality } \\
\text { heterogeneity } \\
\text { of variance }\end{array}$ & $\begin{array}{l}\text { age NS sc } \\
\text { treatment } p=0.016 \\
\text { age+treat } p=0.024\end{array}$ & $\begin{array}{l}\text { age } \\
p=0.025 \\
\text { treatment NS }\end{array}$ \\
\hline $\begin{array}{l}\text { Body mass } \\
\text { BM }\end{array}$ & $\begin{array}{l}\text { normality } \\
\text { heterogeneity } \\
\text { of } \\
\text { variance }\end{array}$ & $\begin{array}{l}\text { age } p<0.0001 \\
\text { treatment } p= \\
\text { age }+ \text { treat NS }\end{array}$ & $\begin{array}{l}\text { age } \\
p<0.0001 \\
\text { treatment NS }\end{array}$ \\
\hline
\end{tabular}




\section{TABLE 5}

\section{STATISTICAL RESULTS OF SYSTEMIC AND RENAL FUNCTION MEASUREMENTS}

\begin{tabular}{|c|c|c|c|}
\hline VARIABLE & ASSUMPTIONS & $\begin{array}{c}\text { 2-WAY } \\
\text { ANOVA RESULT }\end{array}$ & $\begin{array}{l}\text { KRUSKAL- } \\
\text { WALLIS RESUL }\end{array}$ \\
\hline $\begin{array}{l}\text { Mean Arterial } \\
\text { Pressure- MAP }\end{array}$ & $\begin{array}{l}\text { non normality } \\
\text { homogeneity of } \\
\text { variance }\end{array}$ & $\begin{array}{l}\text { age } p=0.0046 \\
\text { treatment } p<0.001 \\
\text { age }+ \text { treat NS }\end{array}$ & $\begin{array}{l}\text { age } p= \\
0.0202 \\
\text { treatment } \\
p=0.0027\end{array}$ \\
\hline $\begin{array}{l}\text { Left kidney } \\
\text { mass } \\
\text { LKM }\end{array}$ & $\begin{array}{l}\text { normality } \\
\text { heterogeneity of } \\
\text { variance }\end{array}$ & $\begin{array}{l}\text { age } p<0.0001 \\
\text { treatment NS } \\
\text { age + treat NS }\end{array}$ & $\begin{array}{l}\text { age } p<0.0001 \\
\text { treatment NS }\end{array}$ \\
\hline $\begin{array}{l}\text { Left kidney } \\
\text { mass: Body } \\
\text { mass ratio } \\
\text { LKM/ BM }\end{array}$ & $\begin{array}{l}\text { normality } \\
\text { heterogeneity of } \\
\text { variance }\end{array}$ & $\begin{array}{l}\text { age NS } \\
\text { treatment } p=0.0128 \\
\text { age + treat } N S\end{array}$ & $\begin{array}{l}\text { age NS } \\
\text { treatment } \\
p=0.0220\end{array}$ \\
\hline $\begin{array}{l}\text { Glomerular } \\
\text { Filtration Rate - } \\
\text { GFR }\end{array}$ & $\begin{array}{l}\text { normality } \\
\text { homogeneity of } \\
\text { variance }\end{array}$ & $\begin{array}{l}\text { age NS } \\
\text { treatment NS } \\
\text { age + treat NS }\end{array}$ & NA \\
\hline $\begin{array}{l}\text { Glomerular } \\
\text { Filtration Rate: } \\
\text { Body Mass } \\
\text { ratio }\end{array}$ & $\begin{array}{l}\text { normality } \\
\text { homogeneity of } \\
\text { variance }\end{array}$ & $\begin{array}{l}\text { age } p<0.0001 \\
\text { treatment NS } \\
\text { age }+ \text { treat NS }\end{array}$ & NA \\
\hline $\begin{array}{l}\text { Renal Plasma } \\
\text { Flow- RPF }\end{array}$ & $\begin{array}{l}\text { non normality } \\
\text { homogeneity of } \\
\text { variance }\end{array}$ & $\begin{array}{l}\text { age NS } \\
\text { treatment NS } \\
\text { age }+ \text { treat NS }\end{array}$ & $\begin{array}{l}\text { age NS } \\
\text { treatment NS }\end{array}$ \\
\hline $\begin{array}{l}\text { Renal Plasma } \\
\text { Flow: Body } \\
\text { Mass ratio }\end{array}$ & $\begin{array}{l}\text { normality } \\
\text { homogeneity of } \\
\text { variance }\end{array}$ & $\begin{array}{l}\text { age } p=0.0428 \\
\text { treatment NS } \\
\text { age + treat NS }\end{array}$ & NA \\
\hline $\begin{array}{l}\text { Filtration } \\
\text { Fraction - } \\
\text { FF }\end{array}$ & $\begin{array}{l}\text { normality } \\
\text { homogeneity of } \\
\text { variance }\end{array}$ & $\begin{array}{l}\text { age } p=0.0370 \\
\text { treatment NS } \\
\text { age + treat NS }\end{array}$ & NA \\
\hline
\end{tabular}


TABLE 6.

\section{STATISTICAL RESULTS OF RENIN-ANGIOTENSIN SYSTEM MEASUREMENTS}

\begin{tabular}{|c|c|c|c|}
\hline VARIABLE & ASSUMPTIONS & $\begin{array}{cr}\text { 2-WAY } & K \\
\text { ANOVA RESULT }\end{array}$ & $\begin{array}{r}\text { RUSKAL-W } \\
\text { RESULT }\end{array}$ \\
\hline $\begin{array}{l}\text { Plasma Renin } \\
\text { Concentration } \\
\text { PRC }\end{array}$ & $\begin{array}{l}\text { non normality } \\
\text { heterogeneity of } \\
\text { variance }\end{array}$ & $\begin{array}{l}\text { age NS } \\
\text { treatment } \\
p<0.0001 \\
\text { age + treat NS }\end{array}$ & $\begin{array}{l}\text { age NS } \\
\text { treatment } \\
p<0.0001\end{array}$ \\
\hline $\begin{array}{l}\text { Kidney Angio- } \\
\text { tensin II concen- } \\
\text { tration- LK Ang II }\end{array}$ & $\begin{array}{l}\text { non normality } \\
\text { heterogeneity of } \\
\text { variance }\end{array}$ & $\begin{array}{l}\text { age NS } \\
\text { treatment } \\
p<0.0001 \\
\text { age + treat NS }\end{array}$ & $\begin{array}{l}\text { age NS } \\
\text { treatment } \\
p<0.0001\end{array}$ \\
\hline $\begin{array}{l}\text { Blood Angioten- } \\
\text { sin II concen- } \\
\text { tration B Ang II }\end{array}$ & $\begin{array}{l}\text { non normality } \\
\text { heterogeneity of } \\
\text { variance }\end{array}$ & $\begin{array}{l}\text { age NS } \\
\text { treatment NS } \\
\text { age }+ \text { treat NS }\end{array}$ & $\begin{array}{l}\text { age NS } \\
\text { treatment } \\
p=0.0398\end{array}$ \\
\hline
\end{tabular}




\section{REFERENCES}

1. Allen D., J. McKnight, I. Kifor, C. Coletti, N. Hollenberg. Converting enzyme inhibition and renal tissue angiotensin II in the rat. Hyperten. 24:516522, 1994.

2. Anderson S., H.G. Rennke, R. Zatz. Glomerular adaptations with normal aging and with long-term converting enzyme inhibition in rats. Am J Physiol. 267: F35-F43, 1994.

3. Anderson S. Nephrology/Fluid and electrolyte disorders. In Cassel C.K., Riesenberg D.E., Sarenin L.B, Welsh J.R. eds. Geriatric Medicine 2nd Ed. New York, Springer Verlag, 301-31, 1990.

4. Anderson S., B.M. Brenner. Effects of aging on the renal glomerulus. Am. J. Med. 80: 435-442, 1986.

5.Anderson S., T.T. Oyama, F.F. Jung, J.R. Ingelfinger. Renin-angiotensin system and the aging kidney. Am Soc Nephrol. 5:937, 1994 (abstr).

6. Avasthi P.S., E.R. Greene, W.F. Voyles, D.C. Fisher. Postprandial renal hemodynamics in humans. Kidney Int. 27:291, 1985 (abstr).

7. Baylis C. Renal responses to acute angiotensin II inhibition and administered angiotensin II in the aging, conscious, chronically catherized rat. Am J Kid Dis, 22:842-850, 1993.

8. Bosch J.P., A. Saccaggi , A. Lauer ,C. Ronco, M. Belledonne, S. Glabman. Renal functional reserve in humans: effect of protein intake of glomerular filtration rate. Am J Med 75: 943-950, 1983.

9. Tisher C.C., K.M. Madson. Anatomy of the kidney. In B.M. Brenner and F.C. Rector Jr, Eds. The Kidney, Philadelphia, WB Saunders Co.1995.

10. Brenner B.M. Nephron adaptation to renal injury or ablation. Mechanisms, benefits and risks. Am J Physiol. 249:F324-337, 1985.

11. Burns K., T. Homma, R.C. Harris. The intrarenal renin-angiotensin system. Seminars in Nephrology 13:13-30, 1993. 
12. Corman B., J. B. Michel. Renin-angiotensin system, converting-enzyme inhibition and kidney function in aging female rats. Am J Physiol 251: R450455, 1986.

13. Duggan J., J. Nussberger, S. Kilfeather, K. O'Malley. Aging and human hormonal and pressor responsiveness to angiotensin II infusion with simultaneous measurement of exogenous and endogenous angiotensin II. Am J Hypertens. 6:641-647, 1993.

14. Duggan J., S. Kilfeather, E. O'Brien, K. O'Malley, J. Nussberger. Effects of aging and hypertension on plasma angiotensin II and platelet angiotensin II receptor density. Am J Hypertens. 5:687-693, 1992.

15. Dzau V.J. Circulating versus local renin-angiotensin system in cardiovascular homeostasis. Circulation 77(suppl I)I-4-I-13, 1988.

16. Epstein M.M., N.K. Hollenberg. Renal 'salt wasting' despite apparently normal renal, adrenal and central nervous system function. Nephron:24,121126, 1979.

17. Epstein M. Aging and the kidney. J. Am. Soc. Nephrol. 7:1106-1122, 1996.

18. Ferder L., F. Inserra, L. Romano, L. Ercole, V. Pszenny. Decreased glomerulosclerosis in aging by angiotensin-converting enzyme inhibitors. J Am Soc Nephrol. 5:1147-1152, 1994.

19. Fox J., S. Guan, A. Hymel, L. Navar. Dietary $\mathrm{Na}$ and ACE inhibition effects on renal tissue angiotensin I and II and ACE activity in rats. Am. J. Physiol.: F902-F909, 1992.

20. Guan S., J. Fox, K. Mitchell, L. Navar. Angiotensin and Angiotensin Converting Enzyme Tissue Levels in Two Kidney, One Clip Hypertensive Rats. Hyperten. 20: 763-767, 1992.

21. Hayashi M., T. Saruta, R. Nakamura, W. Kitajima, E. Kata. Effect of aging on single nephron renin content in rats. Renal Physiol. 4: 17-21, 1981.

22. Hostetter T.H., J.L. Olson, H.G. Rennke, M.A. Venkatachalam, B.M. Brenner. Hyperfiltration in remnant nephrons: a potentially adverse response to renal ablation. Am J Physiol. 241:F85-F93, 1981. 
23. Ingelfinger J.R., V.J.Dzau Molecular biology of renal injury: emphasis on the role of the renin-angiotensin system. J Am Soc Nephrol. 2(suppl 1): S9S20, 1991.

24. Inserra F., L. Romano, E. De Cavanagh, L. Ercole, L. Ferder, R. Gomez. Renal interstitial sclerosis in aging: effects of enalapril and nifedipine. J Am Soc Nephrol. 7:676-680, 1996.

25. Johnston C.I., B. Fabris, K. Jandeleit. Intrarenal renin-angtiotensin system in renal physiology and pathophysiology. Kidney Int. 44(Suppl. 42):S-59-S63, 1993.

26. Johnston C.I. Renin-angiotensin system: a dual tissue and hormonal system for cardiovascular control. J Hypertension 10(suppl7):S13-S26, 1992.

27. Jung, F. F., T.M. Kennefick, J.R. Ingelfinger, J.P. Vora and S. Anderson. Down-regulation of the intrarenal renin-angiotensin system in the aging rat. J. Am. Soc.Nephrol. 5:1573-1580, 1995.

28. Levi, M., J. Rowe. Aging and the kidney. In Schrier R.W., Gottschalck C.W. Eds. Diseases and the Kidney. 5th edition. Boston, Little Brown. 24052428, 1995.

29. Magro A.M., U.H.Rudofsky. Plasma renin activity decrease precedes spontaneous focal glomerular sclerosis in aging rats. Nephron 31: 245$253,1982$.

30. Meyer T.W., T.H. Hostetter, H.G. Rennke, J.L. Noddin, B.M. Brenner. Preservation of renal structure and function by long term protein restriction in rats with reduced renal mass. Kidney Int 23:218, (abstr), 1983.

31. Nunez M., C. Garcia-Iglesias, J.M.Taberno-Romo. Renal management of sodium under indomethacin and aldosterone in the elderly. Age Ageing 9:165-172, 1978.

32. Nussberger J., D. Brunner, B. Waeber, H. Brunner. True versus immunoreactive angiotensin II in human plasma. Hypertension. 7(pt.2):11-17, 1985. 
33. Oliver J. Nephrons and Kidneys: A Quantitative Study of Development and Evolutionary Mammalian Renal Architectonics. New York, Harper Row Publishers, 1968.

34. O'Connor W.J., R.A. Summerill: The effect of a meal of meat on glomerular filtration rate in dogs at normal urine flows. J Physiol. 256: 81-91, 1976.

35. Pettinger W.A., K. Tanaka, K. Keaton, W.B. Campbell, S.W. Brooks. Renin release: an artifact of anesthesia and its implications in rats. Proc. Soc. Exp. Biol. Med. 148: 625-630, 1975.

36. Rouillier C.: General anatomy and histology of the kidney. In Roulier $C$, Muller, AF(eds); The Kidney: Morphology, Biochemistry, Physiology, Vol 1. New York, Academic Press, 61, 1969.

37. SAS Institiute Inc. SAS/STAT User's Guide, Version 4th edition, Volume 1 and 2, Cary, SAS Institute Inc., 1989.

38. Sokal R.R., F.J. Rohlf. Biometry. New York, W.H. Freeman and Co., 1995.

39. SPSS Inc. SPSS Reference Guide, Version 4, Chicago, SPSS Inc, 1990.

40. Schmidt-Nielsen B., R. Odell. Structure and concentrating mechanisms in the mammalian kidney. Am J Physiol 200:1119-1125, 1961.

41. Schoolwerth A.C., R.S. Sandler, P.M. Hoffman, S. Klahr. Effects of nephron reduction and dietary protein content on renal ammoniagenesis in the rat. Kidney Int 7:397-404, 1975.

42. Shannon J.A., N. Jolliffe, H.W. Smith. The excretion of urine in the dog. IV. Effect of maintenance of diet, feeding, etc., upon the quantity of glomerular filtrate. Am J Physiol.101:625-638, 1932.

43. Tank, J.E., J. P. Vora, D. C. Houghton, and S. Anderson. Altered renal vascular responses in the aging rat kidney. Am. J. Physiol. 266: F942-F948, 1994. 
44. Weidmann P., S. De Myttenaere-Bursztein, M. Maxwell, J. De Lima. Effect of aging on plasma renin and aldosterone in normal man. Kidney Internat. 8: 325-333, 1975.

45. Zoja C., A. Remuzzi, D. Corna, N. Perico, T. Bertani, G. Remuzzi. Renal protective effect of angiotensin-converting enzyme inhibition in aging rats. $A m$ J Med 92: 60S-64S, 1992. 